carrying entitlement to a followship, a statutory obligation to provide fellowships for all holders of such posts, and enough new fellowships to provide for them all, the Committee recommends that ontitlement to a fellowship should be limited to titular professors (by decree), assistant profossors and readors, the holders of certain official posts to be enumerated, and full-time university lecturers and senior rescarch officers appointed by the general board as soon as their uppointments have been confirmod until retiring age. The new colleges, like the oxisting colleges, should be empowered to elect to fellow. ships a limited number of those eligible but not entitled to them, and there should be some university posts the holders of which should become entitlod to a college fellowship on appointment, as well as others of which the holder should be assured of eventual entitlement. Somo 160 members of staff are concerned, and the Committee recommends that the University should make available an annual sum sufficient to provide grants for the existing colleges for up to 50 fellowships. Grants of $\$ 300$ each are suggested. Preliminary estimates indicate that a sum of some $£ 35,000-£ 50,000$ would be required for capital expenditure on the new colleges, and it is estimated that for some years to come each college would need to be assured of an annual income of $£ 12,000$. Four of tho richer colleges have alrcady provided a capital grant of $\mathfrak{f 2 9 , 0 0 0}$ and an annual grant for ten years of $£ 18,000$. The Committee also recommends that the procedure for allocating or electing Fellows to the new colloges should be reviewod at the end of five years, and it thinks it is of the highest importance that professorships should be pormanently allocated to the new colleges, but it does not rocommend a professorial allocation of readerships.

Imperial College of Science and Technology

THE 107th annual report of the Governing Body of the Irnperial Collogo of Science and Technology, London, covers the year ended July 31,1964 . During the year the College accepted tho invitation to become a 'Special Institution' and proposed an increaso in the number of undergraduates over the next 4 years, mainly in mathematies, physics and engineering, building up to an incroase of 450 in 1967-68. Proposals submitted to tho University Grants Committee for the College's long-term expansion provide for a further expansion of the College by $1973-74$ to a total of 4,700 students. This would comprise 1,840 postgraduates, 2,460 undergraduates and 400 arehitects, on the assumption that the School of the Architectural Association would be incorporated in the College and the necossary current and capital finance provided. During the year, the number of full-time students rose to 2,979 , undergraduates increasing to 1,824 and postgraduates to 1,155 . The academic staff totalled 516 at tho end of the snssion. In Dacember 1963, IBM (United Kingdom), Ltd., offered the College an IBM 7090 computer and associated equipment free on loan for 5 years. This is being installed in the Electrical Engineering Building and will be available equally to the College, to othor universities within the United Kingdom, and to IBM, on a shared time basis. During the sossion, 745 degrens-including 223 higher dogrees-were awarded by the University to students of the Colloge. Degrees in technological subjects accounted for 56 per cent of the total. In October, as part of the Cambridge 'Television Week, a two-way elosed-circuit television link was established betwoon the University of Cambridge and the College, and used for joint seminars between physics and metallurgy staff and resonrch students, and for a discussion on laboratory work in teaching undergraduate engineers. 'The oxperiment is describod as markedly suecessful. The Rector's roport includes brief roports of research in the various dopartments; lists are also appended of publications during the year and of special lectures and addresses.

\section{The Night Sky in May}

NEw Moons occur on May 1, $12 \mathrm{~h}$ U.T., and May 30, $21 \mathrm{~h}$, and full Moon occurs on May $15,12 \mathrm{~h}$. There is a total eclipse of the Sun on May 30, but it is visible only in the Southern Pacific Ocean. Tho following conjunctions with the Moon occur: May 3, $00 \mathrm{~h}$, Jupiter 0.5 N.; May 9, $20 \mathrm{~h}$, Mars $4^{\circ} \mathrm{S}$.; May 24, $15 \mathrm{~h}$, Saturn $4^{\circ} \mathrm{N}$. Mercury is unfavourably placed for obsorvation. Venus sets at $19 \mathrm{~h} 45 \mathrm{~min}, 20 \mathrm{~h} 35 \mathrm{~min}, 21 \mathrm{~h} 15 \mathrm{~min}$, on May $1,15,31$ respoctively-it will therefore be visible just after sunset towards the ond of the month. Mars sets at $3 \mathrm{~h} 05 \mathrm{~min}$, $2 \mathrm{~h} 10 \mathrm{~min}$, $1 \mathrm{~h} 20 \mathrm{~min}$ at the beginning, middlo and end of tho month respectively; its stellar magnitude is $+0 \cdot 3$; its distance from the Earth on May 15 is 92 million miles and is in Leo. Jupiter sets at $21 \mathrm{~h} 20 \mathrm{~min}, 20 \mathrm{~h}$ 40 min at the beginning and middle of the month respec. tively, becoming too close to the Sun for observation towards tho end of the month. Saturn rises $3 \mathrm{~h} 05 \mathrm{~min}$, $2 \mathrm{~h} 10 \mathrm{~min}, 1 \mathrm{~h} 10 \mathrm{~min}$ at the beginning, middle and end of the month respectively; its stellar magnitude is $+1 \cdot 3$; its distaneo from the Earth is $\mathbf{9 3 4}$ million miles and is in Aquarius. The following occultations of stars brighter than magnitude 6 take place, observation being made at Greenwich: May 10,19 h $46.7 \mathrm{~min}, v \operatorname{Vir}(D)$; May 13, $1 \mathrm{~h} 18.1 \mathrm{~min}, 74 \operatorname{Vir}(D)$; May 13, $19 \mathrm{~h} 56 \mathrm{~min}, x \operatorname{Vir}(D)$. $D$ refers to disappearance. 'The $\eta$ Aquarid meteors are active during the period May 1-8. Conditions of observation are favourable with maximum occurring during May 5. The radiant is at $336^{\circ}$ R.A., $0^{\circ}$ Dec.

\section{Announcements}

Prof. J. H. VAN VLeCk, professor of physics at Harvard University, has received the first Irving Langmuir Award in chemical physics, sponsored by the General Electric Foundation. Prof. Van Vleck received the award in recognition of his investigations of the magnetic properties of chomical systems, in particular of rare-earth ions in crystals and of oxygen and nitric oxide clathrates. It was presented to him by the American Physical Society on March 25, during the March meeting hold at Kansas City. This annual award of 5,000 dollars, honouring the late Dr. Irving Langmuir, Nobel Prize winning scientist of tho General Electric Research Laboratory, is administered jointly by the American Physical Society and the Amorican Chemical Society, cach selecting the recipiont in alternate years.

A. SYmpostum on "Radiation and Terrestrial Eeosysterns", sponsored by the U.S. Atomic Energy Commission and Battelle-North-west, will be held in Richland, Washington, during May 3-5. Further information can be obtained from. Dr. F. P. Hungate, Biology Department, Battello-North-west, P.O. Box 999, Richland, Washington.

AN international symposium on "Cell Difforentiation", organizod by the Agricultural Univorsity of Wageningon, will be held at Wageningen during April 26 29. Furthor information can be obtained from Miss F. Quak, Tristitute of Phytopathological Resoarch, Binnenhaven 12, Wagoningon.

AN international conference on "Continuous Casting of Ferrous and Non-ferrous Alloys" will bo held in the Department of Industrial Metallurgy, University of Birmingham, during April 28 30. Further information can be obtained from the Organizing Socretary, Dopartment of Industrial Metallurgy, the University, Edgbaston, Birmingham 15.

A symposium on "The Chemistry of Polymerization Processes", organized by the Plastics and Polymer Group of the Society of Chemical Industry, will be held at the Institution of Eloctrical Engineers, London, during April 29 30. Further information can be obtained from Dr. W. R. Moore, Department of Chemical 'Technology, Bradford Institute of Technology, Bradford. 